\title{
Explaining the Trust in Rochefoucauld $v$ Boustead
}

\author{
A B Douglas \\ Wolfson College, Cambridge
}

This is a draft of an article to appear in the Conveyancer.

In Rochefoucauld $v$ Boustead,$^{1}$ the Court of Appeal enforced a trust of land despite an absence of written evidence to satisfy s 7 of the Statute of Frauds. ${ }^{2}$ The case has attracted intense academic attention, not because this precise point arises often for decision, but rather as part of wider attempt by academics to explain and rationalise the recent growth of constructive trusts. Some scholars claim Rochefoucauld $v$ Boustead as a constructive trust to draw from it a wide principle under which other wayward and orphan constructive trusts might be sheltered..$^{3}$ Others argue that Rochefoucauld $v$ Boustead concerned an express trust. ${ }^{4}$

This article argues that Rochefoucauld $v$ Boustead is properly understood as an express trust. It will consider the nature of the fraud, the way in which the Statute of Frauds and the fraud must be pleaded, the arguments against a constructive trust and the detailed facts of Rochefoucauld $v$ Boustead as it was pleaded and argued.

\section{The Nature of the Fraud}

The modern equivalent of s 7 of the Statute of Frauds is s 53(1)(b) of the Law of Property Act 1925:

"a declaration of trust respecting any land or any interest therein must be manifested and proved by some writing signed by some person who is able to declare such trust or by his will".

By s 53(2) "resulting, implied or constructive trusts" are exempted from the formality requirement, which is the counterpart of s 8 of the Statute of Frauds.

The proper interpretation of $\mathrm{s} 7$ of the Statute of Frauds was settled by the end of the 18th century. ${ }^{5}$ It is concerned with proof, not validity. The declaration need not be in writing; it can be oral. The date of writing is therefore immaterial. ${ }^{6}$ The writing can be created after the creation of the trust. Indeed, it can come into being as late as during litigation about the trust. ${ }^{7}$ All that is needed is that written evidence be in existence at the date of trial. The date of the creation of the trust may therefore precede the date of the writing. If the evidence is written after the acts creating the trust, there is still an express trust in the meantime; it is just unproveable until the evidence is created. If the evidence is lost, it may become unproveable again. It might sound strange to speak of an unproveable trust, as the practical effect of the Statute is to render the trust unenforceable for lack of evidence, but there is an important difference between a formality relating to proof and a formality relating to validity which will become apparent when considering how the Statute is pleaded.

When there is no writing, the trust will be unproveable, and that will have the effect that the trustee holds the legal title to the land effectively as absolute owner. However, under the doctrine in Rochefoucauld $v$ Boustead, equity will allow a trust to be enforced despite the lack of writing

\footnotetext{
${ }^{1}$ [1897] 1 Ch 196.

2 (1677) 29 Car 2, c 3.

${ }^{3}$ Elias, Explaining Constructive Trusts (Oxford, 1990); Oakley, Constructive Trusts, 3rd ed (Sweet \& Maxwell, 1997) 53-9; McFarlane, "Constructive Trusts Arising on a Receipt of Property Sub Conditione" (2004) 120 LQR 667; McFarlane, The Structure of Property Law (Hart, 2008) 382, 434-5; Gardner, "Reliance-Based Constructive Trusts" in Mitchell, Constructive and Resulting Trusts (Hart, 2010) ch2; Liew, Rationalising Constructive Trusts (Hart, 2017) ch4 (based on Liew, "Rochefoucauld v Boustead (1897)" in Mitchell \& Mitchell, Landmark Cases in Equity (Hart, 2012) ch14).

${ }_{4}^{4}$ Swadling, "The Nature of the Trust in Rochefoucauld $v$ Boustead" in Constructive and Resulting Trusts (n3) ch3; Allen v Snyder [1977] 2 NSWLR 685; Schweitzer v Schweitzer [2012] VSCA 260, [43] and see the references in Liew (n3) fn10.

5 Forster v Hale (1798) 3 Ves 696, 707; Randall v Morgan (1805) 12 Ves 67, 74; Smith v Matthews (1861) 3 De GF \& J 139, 151.

${ }^{6}$ Forster v Hale (n5); Gardner v Rowe (1828) 5 Russ 258; Rochefoucauld (n1), 206.

${ }^{7}$ Hampton $v$ Spencer (1693) 2 Vern 287; Cottington v Fletcher (1740) 2 Atk 155.
} 
providing there is fraud. The fraud with which equity is concerned was defined by Lindley LJ, giving the judgment of the Court of Appeal (Lord Halsbury LC, Lindley and AL Smith LJJ):

"It is further established by a series of cases, the propriety of which cannot now be questioned, that the Statute of Frauds does not prevent the proof of a fraud; and that it is a fraud on the part of a person to whom land is conveyed as a trustee, and who knows it was so conveyed, to deny the trust and claim the land himself. Consequently, notwithstanding the statute, it is competent for a person claiming land conveyed to another to prove by parol evidence that it was so conveyed upon trust for the claimant, and that the grantee, knowing the facts, is denying the trust and relying upon the form of conveyance and the statute, in order to keep the land himself."

This is a definition that has been carefully worded. From this quotation, we can see that there are four clear and separable elements:

"[I]t is a fraud on the part of a person 1) to whom land is conveyed as a trustee, and who 2) knows it was so conveyed, 3) to deny the trust and 4) claim the land himself."

The conduct is precisely defined in elements 3 and 4 , and the circumstances and mental state that generate the fraud are defined in elements 1 and 2 . The denial of the trust (3) to benefit themselves (4) in the circumstances (1) of which the defendant has knowledge (2) together make up this particular type of fraud. If any element is not present, the fraud will not be made out. Let us consider each element in turn.

First, the defendant must have received the land as trustee. If the defendant received land beneficially and was alleged subsequently to have declared a trust, the Statute of Frauds is applicable. ${ }^{9}$ Only in a situation where the defendant is alleged to have received the land as trustee from the beginning can the fraud exception apply. Thus, though the doctrine in Rochefoucauld $v$ Boustead is a significant exception to the Statute of Frauds, it does not deprive it wholly of effect. A beneficial owner who is alleged to have orally created a trust can rely on the absence of writing without needing to engage in a battle over oral testimony. That preserves some of the primary purpose of the Statute of Frauds to prevent hidden oral dispositions of land.10

Secondly, the defendant must know that they received the land as trustee. Lindley LJ in the quotation above states that the defendant "knowing the facts, is denying the trust...". This requirement protects a defendant who received land beneficially but where the transferor later alleges an oral trust to defeat the defendant's title. If there was nothing in the facts to give the defendant knowledge that they were to hold as trustee, then the defendant can rely on the Statute of Frauds with a clear conscience.

Thirdly, the defendant must deny the trust. This is perhaps the most misunderstood element of the test. The denial of the trust is not some denial in the abstract. The fraud of which Lindley LJ spoke involved the use of the Statute of Frauds which must be pleaded and relied on by the defendant in litigation about the trust. The denial of the trust occurs when the defendant pleads the Statute of Frauds as a bar to the plaintiff's case. ${ }^{11}$ This is made clear in the concluding sentence by Lindley LJ quoted above: "the grantee, knowing the facts, is denying the trust and relying upon the form of conveyance and the statute..."12 and later in his judgment where Lindley LJ says "other evidence is admissible in order to prevent the statute from being used in order to commit a fraud". In the Law Times report of Rochefoucauld, Haldane QC also makes the point explicitly in argument: "evidence is admissible, as the case is one of fraud, to prove that there was a trust, and in order to prevent the Statute of Frauds from being raised as a defence to the plaintiff's claim."13 It is not some independent act of denial of the trust separate from the reliance on the Statute of Frauds in litigation. The denial involves the use of the Statute of Frauds itself. This will be discussed in more detail below.

Fourthly, the defendant must be claiming the land for themselves. This suggests that if there were circumstances where the defendant as trustee denied the trust but was not claiming the land for themselves, the Statute of Frauds will apply. Suppose settlor A, who had absolute title to land,

\footnotetext{
8 Rochefoucauld (n1), 206.

9 Wratten v Hunter [1978] 2 NSWLR 367.

${ }^{10}$ Vandervell $v$ IRC [1967] 2 AC 291, 311.

11 See also Lincoln v Wright (1859) 4 De G \& J 16, 22; Re Duke of Marlborough [1894] 2 Ch 133, 141.

12 See $\mathrm{n} 8$.

${ }^{13}$ Rochefoucauld v Boustead (1896) 75 LT 502, 503.
} 
conveyed property to a trustee B, to hold for C. If A afterwards changed their mind and informed B, pointing out that the trust would be unproveable for lack of writing, then B would have the option of either performing the trust and ignoring A, or B could accede to A's request and hold the land for A. In the second situation, if $\mathrm{C}$ were to assert their beneficial interest against $\mathrm{B}, \mathrm{B}$ could then in good faith deny the trust without committing a fraud because in denying the trust $\mathrm{B}$ would not claiming the land for themselves, but rather for the settlor. ${ }^{14}$ This puts $\mathrm{A}$ in the same position as if $\mathrm{A}$ had declared an oral trust for $\mathrm{C}$ directly, when the Statute of Frauds can be relied upon. The doctrine in Rochefoucauld $v$ Boustead only forbids the trustee from denying the trust and claiming the land for themselves as absolute owner.

The fraud that equity is concerned to prevent is a situation where a trustee seeks to upgrade their interest from the limited interest of a trustee to that of an absolute owner, in circumstances where the trustee never ought to have had beneficial ownership. ${ }^{15}$ So where an absolute owner A declares a trust orally for $\mathrm{C}$, but then goes back on their word, A as settlor/trustee was formerly the absolute owner, and by denying the trust effectively reverts back to a state of ownership they already had. They do not, by denying the trust, give to themselves anything they did not previously have. But a person who knowingly receives land as trustee only, never having had beneficial ownership, seeks to use the Statute of Frauds to effectively obtain beneficial ownership, is there a fraud, and equity refuses to allow the Statute of Frauds to be pleaded to block the oral evidence.

\section{Pleading the Statute of Frauds}

To understand how the fraud exception operates, it is necessary to see how the Statute of Frauds must be pleaded, and how and when the question of fraud in the use of the Statute of Frauds would arise. This requires some consideration of the old form of Chancery procedure. This is not just a matter of history. Forms of pleading and action shape the substance of litigation, even today. ${ }^{16}$

Trusts are usually enforced by the beneficiaries as plaintiffs or, in modern English procedural language, claimants. The trustee is the defendant. There are many reasons why a beneficiary might bring a suit against the trustee. An bold example would be where the trustee has flatly refused to acknowledge the beneficiary's interest, but it need not be this severe. The trustee might simply be in breach of trust. Or there might be a suspicion of a breach of trust. The beneficiary may only be seeking a common account (which is available as of right). ${ }^{17}$ Or a third party might be claiming through a beneficiary and asserting title against the trustee. Whatever the situation, the beneficiary as plaintiff will need to plead facts that show a declaration of trust, ${ }^{18}$ and perhaps allege a breach of trust.

The general rule of pleading, both under the old system of Chancery pleading and under modern rules of procedure, ${ }^{19}$ is that it is for the party who is to take advantage of a particular matter to plead it. 20 "In other words, it is enough for each party to make out his own case or defence. He sufficiently establishes the charge or answer for the purposes of pleading if his pleading establishes a prima facie charge or answer. He is not bound to anticipate...". ${ }^{21}$ Since the Statute of Frauds is not concerned with validity, only proof, it does not need to be pleaded by the plaintiff. So in a suit for a common account, a complete case is pleaded by simply alleging that the defendant received land in circumstances that established an express trust and praying for an account. The Statute of Frauds need not be mentioned and at this stage in the pleadings no question of fraud arises.

The first mention of the Statute of Frauds in the pleadings will come from the defendant. The rule, then as now, is that if the defendant wishes to rely on the Statute of Frauds, it must be specifically

\footnotetext{
14 See Feltham, "Informal Trusts and Third Parties" [1987] Conv 246.

${ }_{15}$ Avondale Printers \& Stationers Ltd $v$ Haggie [1979] 2 NZLR 124, 162-3; ISPT Nominees Pty Ltd v Chief Commissioner of State Revenue [2003] NSWSC 697; 53 ATR 527, [334]; Heydon, Leeming \& Turner, Meagher, Gummow \& Lehane's Equity: Doctrines \& Remedies, 5th ed (Butterworths, 2015) [12-125].

${ }_{16}$ Eg, Pilcher v Rawlins (1872) LR 7 Ch App 259; Fox, "Purchase for Value Without Notice" in Davies, Douglas \& Goudkamp, Defences in Equity (Hart, 2018) 53; Oates v Consolidated Capital Services Ltd (2009) 76 NSWLR 69, [124].

17 Libertarian Investments Ltd v Hall (2013) 16 HKCFAR 681.

18 Jackson $v$ North Wales Railway Co (1848) 1 H \& Tw 75, 84-5.

19 Clarke v Callow (1876) 46 LJ QB 53.

${ }^{20}$ Stowel $v$ Lord Zouch (1563) 1 Plow 353, 376.

${ }^{21}$ Chitty, Treatise on Pleading, 7th ed (Sweet, Stevens \& Norton, 1844) vol 1, 254.
} 
pleaded. ${ }^{22}$ If the defendant fails to plead it, it plays no part in the case, and nothing stands in the way of the plaintiff proving an express trust by parol evidence. ${ }^{23}$

Under the old system of Chancery pleading, there were three ways in which a defence could be raised in equity: by demurrer, plea or answer. ${ }^{24}$ An answer, as the name suggests, required the defendant to answer the charges in the plaintiff's bill, so that the parties might join issue. The demurrer and plea, borrowed initially from common law pleadings, ${ }^{25}$ were used to raise legal arguments that would bring the suit to an end without requiring an answer. Unlike the common law, if a demurrer or plea failed, the defendant's case did not fail with it: the demurrer or plea was merely overruled and the defendant was put to answer. ${ }^{26}$ A demurrer lay when the defendant admitted the facts on the bill but argued that the plaintiff's suit failed because of a rule of law or equity. ${ }^{27}$ A plea was a complete defence founded on new matter raised in the plea, and which theoretically demanded the judgment of the court before the defendant could be compelled to make an answer. ${ }^{28}$ Lord Redesdale in his Treatise on Pleadings described its effect as follows:

"A plea is also intended to prevent further proceeding at large, by resting on some point founded on matter stated in the plea; and as it rests on that point merely, it admits, for the purposes of the plea, the truth of the facts contained in the bill, so far as they are not controverted by facts stated in the plea. Upon the sufficiency of this defence the court will also give immediate judgment, supposing the facts stated in it to be true; but the judgment, if favourable to the defendant, is not definitive; for the truth of the plea may be denied by the plaintiff by a replication, and the parties may then proceed to examine witnesses, the one to prove the other to disprove the facts stated in the plea."29

The appropriate way for the defendant to plead the Statute of Frauds was as a plea in bar of the plaintiff's case. ${ }^{30}$ The plea, if successful, would operate as a complete bar to the plaintiff's charges of a trust based on parol evidence. The court does not take notice of the Statute of Frauds unless it is pleaded, so failure to plead it would mean the defendant could not rely upon it, even if it was anticipated in the plaintiff's bill. ${ }^{31}$ Once the plea was raised, the enquiry shifted to dealing first with the validity of the plea. It is at this stage that the plaintiff will make a further argument to defeat the plea of the Statute of Frauds. The plaintiff, having already pleaded that the defendant took the property as an express trustee, now replies ${ }^{32}$ that the plea should be overruled, because the plea of the Statute of Frauds, in the circumstances outlined in the plaintiff's pleadings, would use the Statute as an instrument of fraud. It is in deciding the validity of the plea that the plaintiff raises the argument of fraud for the first time. Note that the plaintiff needs to rely on no new facts, so no further facts need to be pleaded in reply. ${ }^{33}$ The plaintiff has already pleaded that 1) the defendant received the land as trustee, 2) knowing they were trustee. The act of the defendant in raising the Statute of Frauds in their plea amounts to 3) denying the trust and 4) claiming the land for themselves.

In theory, the validity of the plea is to be determined immediately in open court. ${ }^{34}$ But because some of the facts needed to resolve the argument about the validity of the plea are contained in the

${ }_{22}^{2}$ CPR, Pt 16, r 16.5; Tucker, Le Poidevin \& Brightwell, Lewin on Trusts, 20th ed (Sweet \& Maxwell, 2020), [311]; RSC O 19, r 15; RSC (Rev) 1962 O 18, r 8; Clarke v Callow (n19); Hills \& Grant Ltd v Hodson [1934] Ch 53, 62.

${ }^{23}$ Clarke v Callow (n19); James $v$ Smith [1891] 1 Ch 384, 389; Hills \& Grant v Hodson (n22); though a modern court may be more generous in allowing a late amendment: Re Gonin [1979] Ch 16.

${ }_{24}$ Mitford (Lord Redesdale), Pleadings in Chancery, 5th ed (Stevens \& Norton, 1847) ("Redesdale"), 106.

25 Yale, Lord Nottingham's Two Treatises (Cambridge, 1965), 55.

${ }_{26}^{26}$ Redesdale (n24), 16.

${ }^{27} \mathrm{~A}$ demurrer for want of equity was the classic illustration, which alleged that on the facts pleaded there was no matter that fell within any equitable jurisdiction.

28 The plea of purchaser of the legal estate for value without notice is a classic example

${ }_{29}$ Redesdale (n24), 14-15.

${ }^{30}$ Redesdale (n24), 308 ff.

31 Broughton v Snook [1938] Ch 505, 511.

32 This was done by amending the original bill: Ayckbourn, Practice of the High Court of Chancery, 9th ed (Wildy, 1870); and see (1837) 19 Law Mag 133, 136.

33 This is unlike part performance, where the plea of the Statute of Frauds needed to be countered by a plea of further facts of part performance: Maddison v Alderson (1883) 8 App Cas 467, 475; Broughton v Snook (n31); Steadman $v$ Steadman [1976] AC 536; Masterton Homes Pty Ltd v Palm Assets Pty Ltd [2009] NSWCA 234; 261 ALR 382, [38].

34 See n29. 
plaintiff's pleadings, it was common practice for pleas to be stood over to trial and determined together with the final judgment. ${ }^{35}$ But that does not change the logical order of the legal questions raised by the plea: answering the plea comes before answering the bill (the plaintiff's original case). Once the plea of the Statute of Frauds is raised, the court must determine the validity of the plea. The plaintiff argues that the plea is fraudulent, for the purpose of determining whether the plea should be overruled. If the plaintiff is successful in this argument, then the plea is overruled, the defendant is denied the ability to rely on the Statute of Frauds and is put to answer. The parties join issue and the plaintiff is free to prove by parol evidence the case charged in their original statement of claim.

Once the pleading logic is understood, this resolves an apparent paradox in the use of fraud. ${ }^{36}$ Suppose a plaintiff alleges an oral declaration trust and there is no written evidence. To prove that there is a fraud and escape the application of the Statute of Frauds it is necessary to prove that the defendant received the land as trustee to satisfy Lindley LJ's definition of fraud. But the Statute of Frauds prevents oral proof of the declaration of trust. The proof of the trust seems logically prior to the proof of the fraud. So if the Statute of Frauds prevents proof of the trust, it should also prevent proof of the fraud. That paradox is resolved once it is understood that the Statute of Frauds only enters into a case involving a trust of land through the defendant's plea, and the court must determine the validity of the plea first. The order of enquiry is changed: first, is the plea of the Statute valid? The defendant alleges that the plea of the Statute is a fraud, and because the Statute does not prevent proof of a fraud, parol evidence of the trust is let in for the purposes of establishing fraud. Once the fraud is made out, the plea is overruled. The defendant would be put to answer, and must then either admit the express trust or deny it and contest the evidence. Without the Statute of Frauds in play to bar the plaintiff's case, nothing stands in the way of proving their original express trust with parol evidence. It is now no different from a situation where a defendant failed to plead the Statute entirely. The plaintiff can simply prove an express trust with parol evidence. ${ }^{37}$

\section{Arguments against a Constructive Trust}

The positive case in favour of the express trust has been set out above. It is now necessary to refute the arguments in favour of the constructive trust solution. There are broadly two arguments in favour of Rochefoucauld $v$ Boustead being a constructive trust. The first is that a constructive trust arises upon satisfaction of the test for fraud outlined by Lindley LJ. That would require some pleading of some independent fact of "denial of the trust" by the defendant. This is sometimes put as the defendant having "reneged" on a parol agreement that is viewed as promising beneficial interests under a trust. ${ }^{38}$ The second argument is that a constructive trust arose in Rochefoucauld $v$ Boustead from the moment Boustead acquired the land. This constructive trust is alleged to arise independently of the doctrine that the statute of frauds cannot be used as an instrument of fraud. ${ }^{39}$ This will require closer examination of the facts of Rochefoucauld $v$ Boustead and the way the case was argued.

\section{"Reneging" as generating the constructive trust}

The central difficulty with the constructive trust argument lies in identifying when the constructive trust arises. Under English law, in its current state, it is not possible to have a remedial constructive trust. ${ }^{40}$ A constructive trust must have arisen on the facts of the case and the role of the court is simply to declare that it has arisen. A test needs to be specified for when the constructive trust arises, and the description of fraud by Lindley LJ in Rochefoucauld $v$ Boustead is pressed into service for this purpose. Oakley and McFarlane both argue that the constructive trust arises to prevent the defendant from "reneging" on the understanding on which the land was received.

If a court in a Rochefoucauld $v$ Boustead type case is enforcing a constructive trust, and it is not a remedial constructive trust, it would be necessary on this theory for the beneficiary to plead that the defendant engaged in some independent act of denial to satisfy Lindley LJ's definition of fraud. But

35 Lord Nottingham's "Manual of Chancery Practice” in Yale (n25), $101 \S 36$.

${ }^{36}$ Liew (n3), Rationalising Constructive Trusts, 59-60; Landmark Cases, 444.

${ }^{37}$ Clarke v Callow (n19).

38 See Oakley (n3), 53-4; McFarlane (n3), 675-6.

39 Liew (n3).

${ }^{40}$ Re Polly Peck International plc (No 2) [1998] 3 All ER 812, 823-7; Angove's Pty Ltd v Bailey [2016] UKSC 47; [2016] 1 WLR 3179, [27]. 
in many cases this may be entirely artificial. If the beneficiary's claim is based on alleged breaches of trust, are breaches of trust denials of the trust, or is some further act amounting to "denial" needed? A breach of trust may from its very nature be an affirmation of the trust, as where a trustee is alleged to have inadequately exercised a power. ${ }^{41}$ Such a breach could scarcely amount to a denial. Many breaches of trust are explicable only on the ground that a valid trust was in existence and the trustee was purporting to perform its duties under it. ${ }^{42}$ Must it be necessary to identify some further moment when the trustee, like Lady Macbeth, ${ }^{43}$ commits to evil and denies the trust utterly?

If no such denial can be found on the facts, then the only candidate to generate a constructive trust is the act of pleading the Statute of Frauds in the defence. But that causes even more difficulties. A proprietary interest can only arise at the moment the last fact necessary for its creation has arisen, unless it has some retrospective operation. ${ }^{44}$ When a plaintiff brings a suit alleging a parol trust and charging the defendant with breaches of trust, the breach of trust presupposes the existence of a prior valid trust. If the parol express trust is unproveable, and the plaintiff is to rely only on a constructive trust, it would be logical to expect that the constructive trust must have arisen prior to the breaches of trust. But if the event that creates the constructive trust is the denial of the trust, and that only happens when the defendant raises the Statute of Frauds in their defence, then either the constructive trust has some retrospective effect, or somehow equity is able to charge a defendant with breaches of a trust where the breach occurred before the trust arose. The former seems to be barred by English law's resistance to the remedial constructive trust; the latter seems logically absurd. Treating the breach of trust as the denial generating the trust fares little better. Trust and duty should logically precede breach.

This is not just a matter of abstract logic. It may be necessary to determine the precise time the trust arose if third parties are claiming against the beneficiary or the trustee or if for some other reason the priority between competing interests must be established. If a trustee has granted an equitable charge to a bank, and the court is enforcing an express trust the express trust is first in time and the beneficiary has priority over the bank. ${ }^{45}$ If the breach of trust (granting the charge) is seen as a "denial" of the trust to generate a constructive trust, it is less clear whether the beneficiary would have priority. If the act of denial generating a constructive trust was pleading the Statute of Frauds, then a constructive trust could only arise during the litigation, well after the charge was created; the beneficiaries would have no priority. Further examples can be given. Suppose a third party interest arises independently of any act of the trustee that can be said to amount to a denial. What if the trustee becomes insolvent, or the trustee's property is subjected to a charging order, or an order is made against the trustee under Proceeds of Crime legislation, or the trustee is assessed for income, property or estate taxation? Each of these events would be difficult to interpret as a denial of the trust. How would the beneficiary possibly have a beneficial interest except under an express trust?

Moreover, in each of these situations, a plaintiff beneficiary should be able to assert their rights under a parol trust not only against the trustee but also against third parties claiming through the trustee. Otherwise a trustee would be able to commit frauds by granting interests to third parties in breach of trust and relying on the third parties to enforce their interests. The effects of the pleading rules allow the plaintiff to rely on the parol trust because if the trustee were to raise the Statute of Frauds equity would disallow the plea. So too the plaintiff must be able to enforce their beneficial interest against third parties, and if a third party were to seek to rely on the Statute of Frauds, a court would deny the plea as it would to the trustee. This was the way Ungoed-Thomas J approached the effect of the Statute of Frauds in Hodgson v Marks. 46 The plaintiff should not have to wait for a denial in order to establish their rights, and suffer the uncertainty of not knowing when the priority of their rights might arise.

The notion of a constructive trust arising at the point of denial might just be plausible if the original bargain was a passive trust, but what if the parol trust was an active trust where the trustee had a great number of duties, powers and rights against the trust assets, or an exclusion clause? Does the constructive trust that is imposed by equity duplicate all those duties, powers and rights? Not to do

41 Pitt $v$ Holt [2013] 2 AC 108.

${ }^{42}$ Hitch v Stone [2001] EWCA Civ 63; [2001] STC 214, [68] Conaglen, "Sham Trusts" [2008] CLJ 176, 193-7.

${ }^{43}$ Macbeth 1.5.41-55.

${ }^{44}$ Eg, rescission or rectification: Malmesbury v Malmesbury (1862) 31 Beav 407; Shalson v Russo [2005] Ch 281, [122]-[126]; Greater Pacific Investments Pty Ltd v Australian National Industries Ltd (1996) 39 NSWLR 143, 153.

45 Phillips v Phillips (1861) 4 De GF \& J 208, 215-16; Land Registration Act 2002, s 28.

46 [1971] Ch 892. 
so might operate to the prejudice of the trustee who may have acted in reliance on having certain powers and right during the period in which the existence of the trust was assumed by all parties. If indeed a constructive trust included all these terms, then it is essentially the enforcement of an express trust with a slight change of clothes to slip it through the back door. ${ }^{47}$ Far better to call a spade a spade and frankly acknowledge what equity is doing.

The usual situation in which "reneging" is said to occur is a situation where the trustee, as holder of the legal title, obtained the legal title promising to acknowledge certain interests for third parties. If the trustee acts outside the courtroom in a way that seeks to deny the beneficiary the rights they were promised, that could be construed as a "denial" of the arrangement and hence the trust. Bannister $v$ Bannister ${ }^{48}$ has been interpreted as such a case. Mrs Bannister (the beneficiary) agreed to sell title to two cottages to her brother-in-law (the trustee) on an agreement that she would be able to live rent-free in a cottage as long as she wished. The agreement wasn't embodied in the conveyance, and the trustee obtained the cottages at a discount to reflect the arrangement. The trustee served a notice to quit on the beneficiary and commenced possession proceedings. The beneficiary was the defendant to possession proceedings, and raised a trust in a counterclaim, relying on the oral agreement. It seems from the description of the procedural history of the case that the beneficiary framed her claim as a constructive trust in the first instance. It does not seem to have been initially pleaded as an express trust, unlike in Rochefoucauld $v$ Boustead. ${ }^{49}$ Scott LJ discussed "the equitable principle on which a constructive trust is raised" in the following terms:

"The fraud which brings the principle into play arises as soon as the absolute character of the conveyance is set up for the purpose of defeating the beneficial interest, and that is the fraud to cover which the Statute of Frauds or the corresponding provisions of the Law of Property Act, 1925, cannot be called in aid in cases in which no written evidence of the real bargain is available." 50

Does this refer to a reneging of the agreement? The language of "set[ting] up", and the Statute of frauds being "called in aid" shows that what Scott LJ was referring to was the invocation of the Statute of Frauds. No attention seems to be paid to when that might occur, as it was not a live issue in that case. Scott LJ rejected an argument that some further fraud needs to be proved.

However, on the facts of Bannister, there are further facts that could be said to render the trustee's conduct unconscionable, such as the receipt of a discount on the basis of the understanding. Later cases ignored the Statute and focused instead on these elements. So in Binions $v$ Evans, ${ }^{51}$ Lord Denning MR spoke of Bannister as follows:

"Suppose, however, that the defendant did not have an equitable interest at the outset, nevertheless it is quite plain that she obtained one afterwards when the Tredegar Estate sold the cottage. They stipulated with the plaintiffs that they were to take the house 'subject to' the defendant's rights under the agreement. They supplied the plaintiffs with a copy of the contract: and the plaintiffs paid less because of her right to stay there. In these circumstances, this court will impose on the plaintiffs a constructive trust for her benefit: for the simple reason that it would be utterly inequitable for the plaintiffs to turn the defendant out contrary to the stipulation subject to which they took the premises. That seems to me clear from the important decision of Bannister $v$ Bannister...".

And in Lyus v Prowsa Developments Ltd, ${ }^{22}$ Dillon J said:

"It seems to me that the fraud on the part of the defendants in the present case lies not just in relying on the legal rights conferred by an Act of Parliament, but in the first defendant reneging on a positive stipulation in favour of the plaintiffs in the bargain under which the first defendant acquired the land."

These cases change the fraud or unconscionable conduct to a repudiation of an informal arrangement on which property had been acquired. This allows them to find constructive trusts without needing to answer the question whether the informal arrangement would have created a valid express trust.

\footnotetext{
47 Thwaites v Ryan [1984] VR 65.

48 [1948] 2 All ER 133.

49 See n65.

50 Bannister (n48), 136.

51 [1972] Ch 359, 368.

52 [1982] 1 WLR 1044,
} 
Not all arrangements with property, even when the beneficial interest is being dealt with, will satisfy the test of certainty of intention. ${ }^{53}$ The constructive trust allows the court to overcome any potential difficulties of vagueness in the arrangement. These two cases were rationalised in Ashburn Anstalt $v$ Arnold, ${ }^{54}$ Lloyd $v$ Dugdale, ${ }^{55}$ and Chaudhary $v$ Yavuz ${ }^{56}$ on a much more general principle on unconscionability. These later cases show how far the courts travelled from the original fraud articulated by Lindley LJ in Rochefoucauld $v$ Boustead. Though Rochefoucauld and Bannister are sometimes invoked in support in this line of cases, it is clear that they are invoking a wider definition of fraud, and using Rochefoucauld and Bannister analogically. They are justifiable on equity's broad jurisdiction against fraud, ${ }^{57}$ and the use of the constructive trust as a vehicle for the correction of fraud. ${ }^{58}$ This is reflected in the more general reasons of Lord Denning in Binions $v$ Evans, following his discussion of Bannister:

"This imposing of a constructive trust is entirely in accord with the precepts of equity. As Cardozo J once put it: 'A constructive trust is the formula through which the conscience of equity finds expression,' see Beatty $v$ Guggenheim Exploration Co:59 or, as Lord Diplock put it quite recently in Gissing $v$ Gissing, ${ }^{60}$ a constructive trust is created 'whenever the trustee has so conducted himself that it would be inequitable to allow him to deny to the cestui que trust a beneficial interest in the land acquired." 61

The relation of this modern line of cases to Rochefoucauld is best described in Lord Devlin's metaphor in Hedley Byrne \& Co Ltd v Heller \& Partners Ltd:

"[It] may be described either as the widening of an old category or as the creation of a new and similar one. The general conception can be used to produce other categories in the same way. An existing category grows as instances of its application multiply until the time comes when the cell divides." 62

As an explanation for Rochefoucauld itself, "reneging" fits awkwardly with the definition of fraud given by Lindley LJ and the use of the Statute of Frauds since this notion was developed in a line of cases that moved significantly away from the narrow grounds of the Statute of Frauds to a wider conception of fraud. The language comes from Lyus $v$ Prowsa, as does the concept. It would be better that the two doctrines are treated as divided cells and kept separate.

\section{A constructive trust from the beginning?}

A more strident argument against the express trust is put forward by Liew, ${ }^{63}$ who argues that Rochefoucauld $v$ Boustead should be understood as a constructive trust from the moment the property was first received, based on intention and reliance. To a modern reader, this certainly is a plausible basis on which Rochefoucauld $v$ Boustead could have been decided. However, as an explanation of what Rochefoucauld actually decided, based on the way it was pleaded and argued, it does not work. There is no hint of reliance as a basis for the trust in the judgment of Lindley LJ, the argument of Haldane QC, or the pleadings. A decision is only authority for what it decides, not what it could have decided. ${ }^{64}$

In order to consider what Rochefoucauld $v$ Boustead actually decided, it is useful to see the way the case was pleaded and argued. The report of the facts in the Law Reports does not give a complete picture of the facts. The following account is taken from the pleadings and order of the Court of Appeal

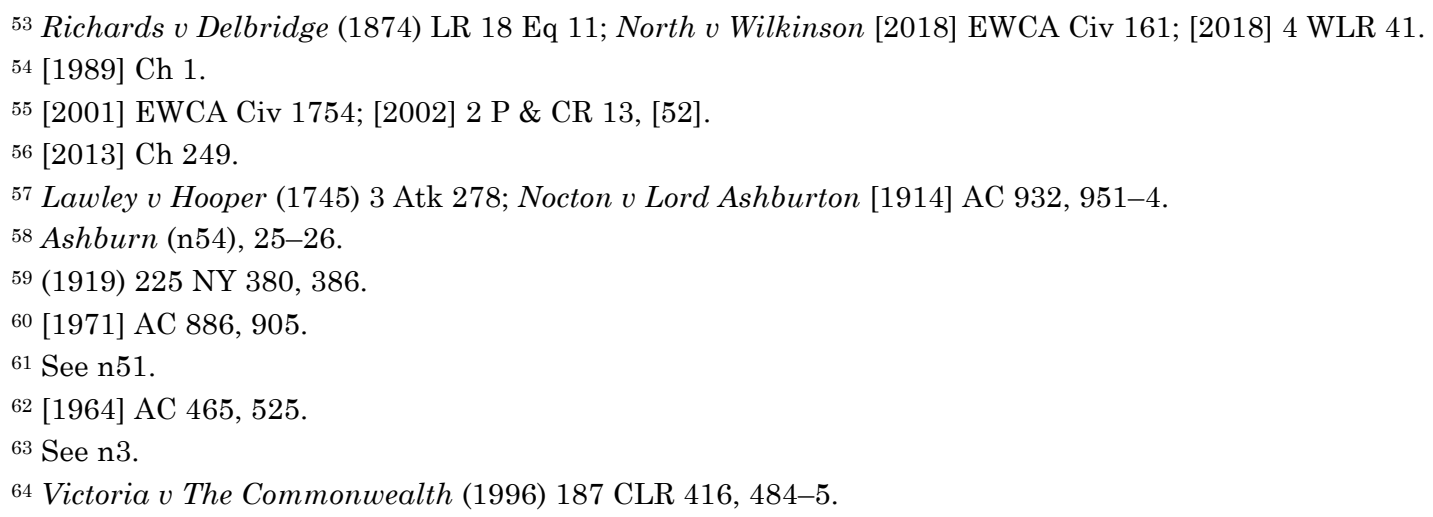


in Rochefoucauld $v$ Boustead in the National Archives. ${ }^{65}$ It is supplemented at times from the recent reconstruction of the facts by Allen which relies on contemporary historical sources. 66

The plaintiff, Emily, the Comtesse de la Rochefoucauld, sought a declaration that the defendant purchased the land "as trustee for the Plaintiffs", together with an account of the trustee's dealings. 67 The order of the Court of Appeal gave the plaintiff the relief sought. The text of the declaration, after reversing the trial judgment, is:

"DECLARE that the Defendant purchased the [land] as trustee for the Plaintiff the Comtesse de la Rochefoucauld subject to his lien for the moneys advanced by him for such purchase and for all sums advanced by him to or on behalf of the said Plaintiff and for all proper advances disbursements and outlay for improvements or otherwise in relation to the cultivation management and upkeep of the said estates or any of them and for his costs and expenses properly incurred in connexion with the said purchase and generally in relation to the said estates or any of them during such time as the said estates were in the possession or under the control and management of the Defendant as trustee for the said Plaintiff with interest for the same respectively at the rate of Six pounds per centum per annum and for his commission upon all transactions in connexion with the sale of the crops and produce of the said estates or any of them and upon his disbursements in relation thereto."68

The land at the heart of the litigation was a set of coffee plantations in Ceylon known as the Delmar estates. Emily inherited it from her adoptive parents, and it came to her in her own right, though subject to a mortgage and an annuity in favour of her first husband, Captain Cavendish. Emily soon after left Cavendish and began a relationship with her future second husband. This precipitated an acrimonious divorce on the ground of adultery, in which the divorce court ordered that the Delmar estates be assigned to trustees to be held under the terms of the divorce orders, with Cavendish to hold the majority of the beneficial interest. This was never done. Emily did all that she could to avoid the divorce orders. She fled to France and joined French aristocratic society. She remained registered proprietor of the estates under Ceylon law. Her later actions relating to the Delmar estates are explicable only in light of a desire to keep the land out of Cavendish's reach. Eventually she was able to settle with Cavendish, but that was after the events leading to the creation of the trust in Rochefoucauld.

By the time the divorce had gone through, the mortgagee of the Delmar Estates was the Société Générale de Commerce et d'Industrie at Amsterdam, a Dutch company. The Société was a mortgagee in possession, and had an arrangement with Emily that it would make her "annual payments to be regulated by the amount of the surplus profits for each year remaining in the hands of the [Société] after providing for the interest commission and other charges in the said agreement" but with a minimum annual payment of $£ 2,500 .{ }^{69}$ This was not an ordinary commercial mortgage.

The Société then fell into liquidation. It wished to be rid of the mortgage. Now Mr Boustead enters the picture. Boustead was a professional coffee estate manager with extensive business in Ceylon and offices in London. Desiring to keep the land out of Cavendish's reach, Emily's friend, Mr Duff, hatched a plan. Mr Duff would supply the money to redeem the mortgage, and Boustead would "take over the account and conduct the sales of the produce of the estates in London upon the customary terms and conditions applicable to the management of Ceylon Estates in the City of London."70 To keep it away from the eye of the divorce court, the Société would "foreclose its mortgage" and sell the estates to Duff and Boustead "at a reserve price to be fixed by the parties provided in the said agreement". ${ }^{71}$ Duff and Boustead would hold the estates "for and on behalf of the Plaintiff Comtesse and for her benefit subject to the repayment of the monies advanced by them for the said purchase and the proper charges incidental to such purchase and to the management of the said estates out of

\footnotetext{
65 National Archives: J54/910 (containing the Statement of Claim (hereafter the "Pleadings")) and J15/2262 (the Order of the Court of Appeal).

${ }^{66}$ Allen, "Ceylon Coffee, the Comtesse and the Consignee: A Historical Reappraisal of Rochefoucauld v Boustead" (2015) JLH 43.

67 Pleadings (n65).

68 TNA: J 15/2262. This gives effect in more detail to the order proposed by Lindley LJ in his judgment: [1897] 1

Ch 196, 212.

69 Pleadings (n65), [8].

70 Ibid, [10].

${ }^{71}$ Ibid, [12]
} 
the proceeds of the sale of the produce of the said estates." 72 Duff then withdrew from the arrangement and Boustead carried out the whole scheme himself.

The sale went according to plan. Boustead purchased the estates at far less than their commercial value. ${ }^{73}$ Boustead took over the sole control of the management and sale of the coffee plantation output. He remitted regular payments of income to the Comtesse. He also gave her regular information about the plantations.

Then tragedy came to Ceylon. Coffee rust fungus was its name. ${ }^{74}$ In the $1870 \mathrm{~s}$, a plague swept through the coffee plantations in Ceylon. Boustead, whose firm specialised in managing coffee plantations, fell into serious financial difficulties. In the late $1870 \mathrm{~s}$, Boustead began in secret to mortgage the Delmar estates. The probable aim was to keep his business afloat assuming that when things turned around, he could repay the money - the sort of well-intended breach of trust that must often happen when a trustee gives into temptation to dip into their client's funds. After all, the only crop Emily was interested in was a regular supply of cash. By 1880, Boustead was bankrupt and his firm was in liquidation. Emily then discovered the breaches of trust: the trustee-in-bankruptcy stopped her income. Owing to a lack of funds she was (she claimed) unable to enforce her claim for many years. She must have lived a pitiable existence amongst the French aristocracy. Boustead was still in touch with her, sending her letters promising that things would soon turn around both in the Ceylon coffee industry and his own financial situation. ${ }^{75}$ He was clearly still purporting to work in her favour, although sadly in this period he had to destroy his books of accounts on the estates as "he had no room for them". ${ }^{76}$ Books, after all, are very bulky. By 1896, things had evidently turned around for Emily - she was able to scrape together the fee to hire Haldane QC as her counsel in the Court of Appeal.

Boustead's actions are explicable on the basis that he wished to maintain good relations with the landowners in Ceylon, as his business in managing Ceylon estates depended on it. He continued to devote his efforts to managing Ceylon estates, and his obituary credits him with being "instrumental in securing the adoption of the tea-plant in place of coffee, which led to the ultimate recovery of the island"77.

These elaborate facts demonstrate that Boustead was in the business of being a trustee. His actions in purchasing the Delmar estates, managing them, his correspondence with Emily and his subsequent efforts all show he was an active trustee. Emily's case was that Boustead purchased the land as trustee under the pleaded agreement, which is more than sufficient to demonstrate that at the time of the purchase of the estates Boustead intended to act as trustee for the Comtesse. Boustead's correspondence and actions before and after the acquisition of the estate are consistent with this. That this was the Court of Appeal's decision appears clearly from the following statement by Lindley LJ:

"The trust which the plaintiff has established is clearly an express trust within the meaning of that expression as explained in Soar $v$ Ashwell. ${ }^{78}$ The trust is one which both plaintiff and defendant intended to create. This case is not one in which an equitable obligation arises although there may have been no intention to create a trust. The intention to create a trust existed from the first."

While there is perhaps some uncertainty over the meaning of "express trust" because of the further words "within the meaning of that expression as explained in Soar $v$ Ashwell", 79 the three sentences that follow make clear that this is not a constructive trust. It is a trust that arises solely because of the intention of the parties, ie, an express trust.

\footnotetext{
72 Ibid, [13].

74 Allen (n66), 64.

75 Rochefoucauld (n1), 198-200.

76 Ibid, 200.

77 Institution of Civil Engineers: Obituaries (1905).

78 [1893] 2 QB 390

79 See Swadling (n4), 100-3.
}

73 Pleadings (n65), [21], narrates that $£ 15,000$ remained in the hands of the Sociéte after the account on the mortgage was settled, which caused the probate court to vary the divorce order. The new order only required that that balance sum be transferred to two trustees to stand on trusts for the divorce terms. It seems therefore that the sale accomplished its goal of keeping the estates away from Cavendish. 
Liew's analysis of Rochefoucauld is focused around the question: who was the settlor of the trust? He comes to the conclusion that no one could possibly have been the settlor of the trust on the facts. But it is tolerably clear that if a settlor needs to be identified it was probably Boustead, as if it was Emily she could have created the writing herself. Liew argues that Boustead could not have been the settlor as he did not have, even for a scintilla temporis, the unencumbered title to the Delmar estates. ${ }^{80}$ This seems to mistake the way in which a trust is declared. A declaration of trust is not an incantation that needs to be performed over property in one's hands. Where a person intends to acquire property and hold it on trust from the beginning, the intention may be formed before the acquisition of the property, but it continues down to the moment of acquisition, and it is not clear why equity would not give effect to it. A declaration can slightly precede the getting in of the title. ${ }^{81}$

Liew at times appears to suggest that no underlying parol express trust could have come into existence in Rochefoucauld, and that only a constructive trust could arise on the facts. If that were so, then it seems strange that any issue of compliance with s 7 of the Statute of Frauds would arise. Surely if a plaintiff had pleaded a constructive trust, the plea of s 7 of the Statute of Frauds would be pointless in light of s 8 of the Statute of Frauds. The plaintiff would not seek to counter the plea by arguing that the Statute of Frauds cannot be used as an instrument of Fraud. She would just have relied on s 8 . There may well have been some doubt about the extent of s 8 in the past, ${ }^{82}$ but certainly this argument could not apply to the modern s 53(2) of the Law of Property Act.

No doubt the facts of Rochefoucauld could support a constructive trust based on detriment on the part of Rochefoucauld, as she would undoubted not have agreed to have Boustead purchase the property and give up her equity of redemption. Moreover, as trustee, Boustead's firm received the benefit of having the Delmar estates to manage, which could be viewed as consideration. Perhaps today counsel might choose to argue such a set of facts as a constructive trust. But in Rochefoucauld the pleadings and argument used those facts only to establish the intentions of the parties to establish a trust upon the acquisition of the land by Boustead. The client only needs to win once.

\section{Conclusion}

Once it becomes clear how the Statute of Frauds is to be pleaded in a case involving a parol trust, it is clear that a constructive trust is not necessary to explain the result in Rochefoucauld $v$ Boustead. Although it is possible on the modern case law that a constructive trust could be applied to similar facts, the way the case was pleaded and argued suggests that it was an express trust that the Court of Appeal was applying. Moreover, the difficulty in identifying when a constructive trust might arise on the facts suggests that the express trust solution is the simpler one. This suggests that when a trust arises in response to intention and intention alone, the trust enforced is an express trust, not a constructive trust.

\footnotetext{
80 Page 431.

81 See Kilpin v Kilpin (1834) 1 My \& K 520, 539; DKLR Holding Co (No 2) Pty Ltd v Commissioner of Stamp Duties (NSW) (1982) 149 CLR 431, 454; Kaki v Kaki [2015] EWHC 3692 (Ch), [53]; Lewin (n22), [3-014]; Wilde, "Valid Trust Declarations Over Property Not Owned By the Settlor or Over Unascertainable Property" (2020) 26 T\&T 168.

82 Allen, (n66).
} 